\title{
Jennifer Anne Bourne (1946-2015): an Appreciation
}

\author{
TWIDALE, C.R. \\ Geology and Geophysics, School of Physical Sciences, University of Adelaide, South Australia
}

https://doi.org/10.17979/cadlaxe.2017.39.0.3560

I met Jennie Bourne when she took my Geomorphology courses, beginning in 1966. She brought to her work a critical and questing mind, an enthusiasm for field work, and a love and respect for words and syntax. She was also a leader. She earned a First Class Honours degree. After marriage and a first child she embarked on research on granite landforms on Eyre Peninsula that she presented for an MA. Then followed a productive, period of research under the auspices of ARC grants.

She took a break from academic life to have her second child but returned to take doctorate with work on the western piedmont of the central Flinders Ranges. There followed about 20 years of fruitful research, mainly based in granitic terrains but on a variety of topics and areas, including for example karst in West Malaysia and the dating paleodunes in central and southern Australia.

Jennie had a keen eye backed by wide reading. She had an eye for anomalies, and the ability and tenacity to seek the evidence. She published some 80 peer- reviewed papers and edited two books. Like her (and my) friend and colleague Liz Campbell, Jennie would have been a superb copy editor for she had an eagle eye for any transposition or other flaw on the printed page.
She was also a rigorous tutor and demonstrator. She was punctilious in marking and written work handed in , not hesitating to award warm praise or acid comment. She also enjoyed organising requested group tours (teachers from Singapore, students and staff from Köln) and generously gave of her time for individual visitors (e,g. from Japan, Germany, Sweden, USA, Pakistan, Spain) keen see our research areas at first hand.

Jennie revelled in field work. It was one long adventure, for things were never as the books said they ought to be. The trip to Uluru and Kata Tjuta with her mother Noreen (who supported her daughter in all her academic endeavours, including acting as a field companion, and from whom Jennie acquired her love and interest in words and grammar) was especially enjoyable and rewarding. She also enjoyed conferences. The field excursion to north western Spain in 1991, and the IGU meetings in Hamilton, Ontario (1993) and Singapore (1995) come readily to mind. Of course here were occasional mishaps; a rollover east of Birdsville; a long walk as a result of being misdirected on to an abandoned track west of Norseman; what was in retrospect though not at the time, an exciting run through teem- 


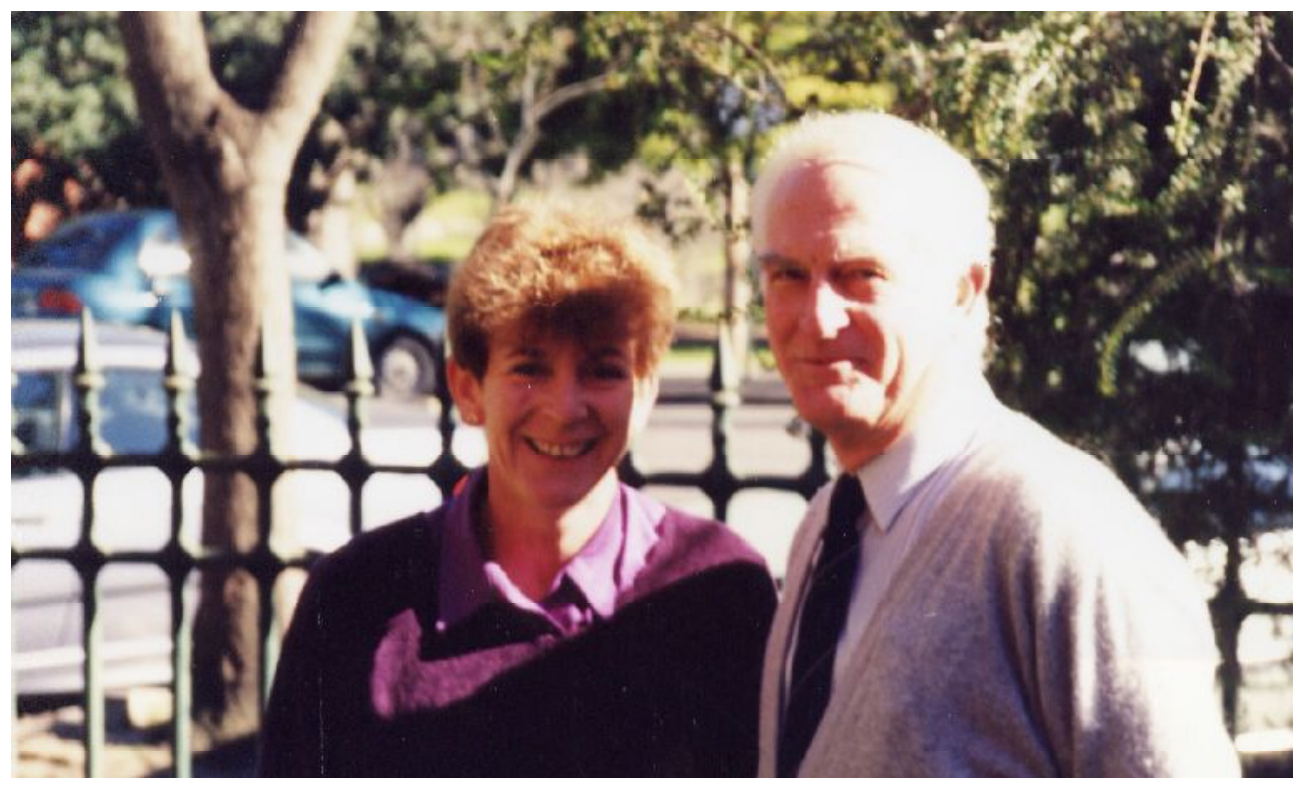

ing rain and rising creeks on the Birdsville track. Jennie handled such challenging adventures with aplomb.

In addition to her academic work, Jennie had many and diverse other interests. In younger days she was a hard driving sports person. She also supported amateur theatre. But orienteering, the Field Geology Club, (her childrens' school) committees, her (high school) Old Students society, all called on her not just as a member but because she was a gifted and efficient administrator, an office holder. They all took time. Jennie's calendar was full months ahead of time, causing concern for some close to her.

Jennie lived a full life. I think we were both slowing down, but it all came to an unexpected and shattering end late in 2015. We had a short field trip to Eyre Peninsula mainly concerned with monitoring sites bearing the imprint recent and continuing tectonic movements. Jennie mentioned a vague abdominal discomfort, and undertook to consult her family doctor. Scans and tests revealed pancreatic cancer. Jennie decided to have treatment but for medical reasons chemotherapy did not begin until Wednesday 18 November. It was agreed someone should sit with Jennie for the first few days of treatment in case of unexpected difficulties. I sat with her all day on Thursday $19^{\text {th. }}$ Naturally, we the reminisced, but Jennie was well aware of her predicament, and we considered various scenarios. She was optimistic and talked about the trips to the Yilgarn and the Northern Territory we had planned (and could fund) but obviously had to defer yet again. She also urged that come what may the projects and papers we had in train should be finalised. Physically she appeared to be comfortable but overnight, when a female friend was staying with her, she experienced mild nausea. Jennie's sister sat with her on the Friday, but apparently 
Jennie said she was managing quite well and wanted time to herself. She was alone that evening. At about 9 p.m. she was talking on the 'phone to her husband who was interstate on golfing business, when she collapsed and died, suddenly, but mercifully, quickly.

Jennie had many talents, She was possessed of a quick intelligence and a finely tuned sense of humour. She had a long standing interest that amounted to a passion for understanding landscape, but in addition touched the lives of many of those around her who will remember her with respect, admiration, and affection.

At the personal level, Jennie and I worked together, albeit with interruptions, for some 50 years. Ours was a productive and enjoyable professional partnership and also a true friendship. I count myself privileged to have known and worked with her.

C. $\mathrm{R}$ Twidale 